\title{
A Review of Sustainable Urban Drainage Systems Considering the Climate Change and Urbanization Impacts
}

\section{Qianqian Zhou}

School of Civil and Transportation Engineering, Guangdong University of Technology, Waihuan Xi Road, Guangzhou 510006, China; E-Mail: qiaz@gdut.edu.cn; Tel.: +86-020-3932-2515;

Fax: +86-020-3932-2511

Received: 27 February 2014; in revised form: 12 April 2014 / Accepted: 14 April 2014 /

Published: 22 April 2014

\begin{abstract}
Climate change and urbanization are converging to challenge city drainage infrastructure due to their adverse impacts on precipitation extremes and the environment of urban areas. Sustainable drainage systems have gained growing public interest in recent years, as a result of its positive effects on water quality and quantity issues and additional recreational amenities perceived in the urban landscape. This paper reviews recent progress in sustainable drainage development based on literature across different disciplinary fields. After presenting the key elements and criteria of sustainable drainage design, various devices and examples of sustainable drainage systems are introduced. The state-of-the-art model approaches and decision-aid tools for assessing the sustainable alternatives are discussed and compared. The paper further explores some limitations and difficulties in the application of the innovative solutions and suggests an integrated and trans-disciplinary approach for sustainable drainage design.
\end{abstract}

Keywords: sustainable drainage systems; urban drainage; stormwater

\section{Introduction}

For a long time, urban drainage systems have existed as a vital city infrastructure to collect and convey stormwater and wastewater away from urban areas [1,2]. Despite development over the years, it remains a significant challenge to design an effective functioning drainage system. In particular, impacts due to climate change and urbanization have been widely acknowledged, which could entail a substantial increase in the frequency and magnitude of urban flooding in many regions of the world [3-6]. At the 
same time, water quality problems also emerge as a result of urbanization that increases the variety and amount of pollutants and nutrients in receiving water bodies [7-9].

The conventional drainage system is mainly a single-objective oriented design with its focus on water quantity control. Today's drainage solutions also highlight the need to embrace more deliberately the other important aspects in urban water management, such as runoff quality, visual amenity, recreational value, ecological protection and multiple water uses [1,10-13]. Water quality has become increasingly significant in the design of urban drainage as a result of a wider political recognition of sustainability. A good example is the EU Water Framework Directive (WFD) that sets targets for good ecological status of all watercourses. This illustrates the current problem of aquatic environment protection and the urgent demand of developing strategies to cope with pollutants to receiving water bodies [14,15]. Besides environmental concerns, there also has been increasing criticism on the limited capacity and flexibility of conventional sewer systems to adapt to future climatic variability and urbanization [16,17].

On the other hand, since the Brundtland Report, the Rio declaration and Agenda 21, sustainable drainage systems have been highly promoted as an alternative and/or complement to the traditional approach to address long-term sustainability in the design of the system $[2,11,18]$. There is a growing trend towards managing water in a more sustainable way by activating its natural behaviors and process in the urban environment [19-21]. Unlike conventional drainage focusing on the "end-of-pipe" or "at the point of the problem" solutions [22], with small and decentralized techniques, sustainable drainage systems can largely alleviate the adverse impacts of non-point source pollution to urban water bodies [10,23,24]. Such solutions rely on local treatment, retention, re-use, infiltration and conveyance of water runoff in urban areas and thus are in better agreement with sustainable principles [19,25]. At the same time, there is rising acknowledgement of the potential of such systems with respect to their positive effects on urban landscape $[11,26]$. It is suggested to treat water as a positive source in sustainable drainage design to create new recreational sites in the urban landscape $[12,13]$. By doing so, the urban water is no longer hidden from the public, but used as an asset to increase user satisfaction and perceived values [5,27].

Sustainable drainage design is a multi-disciplinary research field that requires knowledge from specialists with different backgrounds; this paper therefore aims to give an overview of the status and emerging studies of sustainable drainage for researchers that are interested in participating in its development.

\subsection{Drivers}

\subsubsection{Impacts of Climate Change and Urbanization}

Climate change has been widely acknowledged as a global issue due to its anticipated impacts on urban water systems in terms of changes in water runoff and urban flooding [28-31]. Many scholars have reported in their studies that the expected increase in design intensities due to climate change can reach $20 \%-80 \%$, depending on the region [32-34]. This has posed a huge challenge to the current drainage system that was designed based on a certain return period. The system is therefore faced with severe capacity problems in coping with the increasing amount of water due to climate change impacts. More importantly, future drainage design needs to take the increased frequency and intensity of precipitation into account in order to maintain an acceptable frequency of system overloading [35,36]. 
Urbanization represents another essential factor influencing the quantity and quality of urban water in cities. The process of city development can not only cause a significant change in runoff patterns in terms of both peak flow volumes and speed of runoff due to its impacts on impervious surfaces [3,4], but also vulnerabilities to flood hazards due to the change in urban intensity and distribution $[5,37,38]$. Meanwhile, land cover modifications generally associated with the economic explosion, such as removal of vegetative surface, replacement of raw land with impervious pavements, clearance and filling of natural ponds and streams, could induce increased amount of pollutants and harm the quality of urban water systems [7,39-42].

\subsubsection{Challenges to Conventional Drainage Systems}

Conventional drainage systems are designed to collect and transport water runoff from urban areas as quickly as possible via sewer networks and water treatment facilities to nearby receiving water bodies $[1,11]$. The main goal is to manage water volume in order to avoid urban flooding in city areas. The water is treated as a nuisance in the landscape and thus transported in a manner of "out of sight and out of mind" $[43,44]$. That is to say in the design of conventional drainage system there is limited concern for water quality issues and even less for its amenity and recreational values.

Many researchers have raised their concerns for the long-term sustainability of traditional drainage solutions by exploring their negative impacts on urban environments $[25,45,46]$. Stewart and Hytiris [47] talked about the pollution to receiving watercourses through combined sewer overflows (CSOs); the strong environmental interference of conventional drainage has also been criticized [48,49]. More notably, the traditional system is comprised of a large number of structural measures, such as concrete pipes and underground basins. The costs and time needed for restoration and installation of drainage network are tremendous [37]. This means the conventional system in many cases has to be expanded by bits and pieces and therefore lacks sufficient flexibility to adapt to critical circumstances [16,50]. In facing climate change and urbanization, expanding the conventional underground pipe system may not meet the general criteria of sustainability $[43,48]$.

\section{Terms and Cases of Sustainable Drainage Systems}

The techniques of sustainable drainage systems are widely recommended and applied in many parts of the world, whereas the terminology varies in different regions, but with similar design philosophies. In Europe, Sustainable Urban Drainage System (SUDS) is used with its main focus on maintaining good public health, protecting valuable water resources from pollution and preserving biological diversity and natural resources for future needs [29,48,51]. In Australia, the term Water Sensitive Urban Design (WSUD) was proposed as a catchment-wide approach of which SUDS is a part and mainly refers to a planning and engineering approach to sustainably integrate urban water management into city landscape to minimize environmental degradation and achieve harmony between water and the urban environment [25,52,53]. SUDS is known as Low-Impact Development (LID) in the United States and Canada, which describes an approach promoting the interaction of natural processes with the urban environment to preserve and recreate ecosystems for water management [54]. LID puts the emphasis on conserving and using natural features in combination with small-scale hydrological controls to mitigate 
adverse impacts of urbanization [42,55,56]. Examples of similar approaches are Best Management Practices (BMP) in the United States and LIUDD (low impact urban design and development) in New Zealand.

As a result of the promotion of sustainability, several major research projects have been initiated worldwide. In Denmark, large national research programs include the "Water in urban areas" project working on transformation of the city water infrastructure to climatically robust systems [57], and the 2BG "Black, Blue \& Green" project committed to integrated infrastructure planning for sustainable urban water systems [58]. The working papers from 2BG further expound their main goals and include case studies on sustainable urban drainage design implemented in Denmark and the Netherlands [58]. In the United Kingdom, the Construction Industry Research and Information Association (CIRIA) promotes sustainable drainage systems and also published a series of documents on design practices and applied projects [19]. In Ireland, Dublin's strategic drainage study involves several local authorities to perform an in-depth drainage assessment of integrated constructed wetlands [59]. In Sweden, a large six-year research project entitled "Sustainable Urban Water Management" was initiated by the Swedish Foundation for Strategic Research Programme with its focus on protecting valuable water resources in urban areas [48,60]. In Australia, one of the largest research activities on sustainable drainage solutions is the Cooperative Research Centre (CRC) for Water Sensitive Cities, which brings together over 70 inter-disciplinary partners to deliver sustainable water strategies facilitating transformation of the city into a more livable and resilient environment [61-63].

\section{Previous Reviews}

Wilderer [37] discussed how to apply the concepts of sustainable water management in rural and urban areas via diverse means. The paper addressed the necessity of taking into account multiple aspects (e.g., engineering, economical, administrative and cultural) in research to allow efficient application. Ashley, Garvin, Pasche, Vassilopoulos and Zevenbergen [19] present an overview of the prevalent SUDS components nowadays and showed the potential of integrating SUDS with traditional conveyance systems to satisfy both quality and quantity needs of flood management. Charlesworth [20] showed a review with more specific focus on vegetated and hard-engineering SUDS devices applied for climate change adaptation and mitigation in multi-site case studies. The paper emphasized the need of developing retrofiring technologies to existing buildings and built-up areas in SUDS design. From a more technical point of view, Elliott and Trowsdale [42] assessed 10 models with regard to their capability and relevance to sustainable drainage systems. The paper provides insights into the pros and cons of the reviewed models in response to different requirements of the various SUDS devices. From a management and governing perspective, Brown and Farrelly [64] explored transition bundles from conventional drainage approaches to sustainable solutions and revealed that the barriers are largely socio-institutional rather than technical. Butler and Parkinson [51] addressed new elements of sustainable drainage design and strategies to facilitate the transition from current practices to the new paradigm. To facilitate decisions on SUDS, Lai et al. reviewed a multi-criteria decision aid for integrated sustainability assessment, where three other popular decision-making support tools were also analyzed and compared [65]. All of these previous reviews provide valuable background on the concepts, features, objectives, techniques and tools for sustainable drainage design, with a specific focus on one of the components. 


\section{Sustainable Perspectives and Criteria}

Over time, urban drainage has played different roles in cities. Earlier objectives of urban drainage include provision of a convenient cleaning mechanism of wastes for public hygiene and an efficient conveyance facility for flood protection. In recent years, additional focus has been on environmental protection and the recreational benefits of urban drainage [43]. Despite the various objectives and criteria of drainage systems' indifferent time periods, nowadays there is general agreement that sustainable drainage should integrate water quantity, water quality, and biodiversity and amenity aspects into design, namely the SUDS triangle [11,20,66]. In addition, several researchers called forth a renewed focus on public health and hygiene in SUDS design [48,67,68]. On the basis of these fundamental elements, Ellis et al. [69], Berke [70] and Makropoulos et al. [71] further explored four primary potential sustainability criteria: technical, environmental, social and economic factors. Each criterion contains sub-indicators enabling an assessment of drainage systems with regard to its economic evaluation, functional performance, resource utilization, environmental impacts, etc.

The sustainable criteria for urban drainage has become a great challenge, as this new paradigm needs to employ various disciplines of engineering and sciences to take into account all parts of the urban water cycle in management to ensure economic, social, ecological and environmental sustainability [63,72]. This requires a rather complex approach beyond the traditional one with its narrow focus mainly on the physical performance of the system [73,74]. Many researchers have promoted an integrated trans-disciplinary approach in an attempt to embrace and accommodate different key criteria for future drainage systems $[46,72,75,76]$. In this way, the design of urban drainage will no longer be formulated only based on single technical standards; more attentions will be paid to solutions with benefits for flooding management, spatial design and nature conservation. One good example is the "three-point" approach introduced by e.g., Geldof and Kluck [77] and Fratini, Geldof, Kluck and Mikkelsen [27]. This approach seeks to tackle the conflicts between the three typical design domains (daily amenity, technical optimization and extreme climatic conditions, respectively) of urban drainage and results in an integrated regime where different groups of values and professionals collaborate in the drainage design.

\section{Techniques}

SUDS are a range of drainage techniques and devices allowing for runoff attenuation and mitigation, pollutants reduction and amenity construction [19]. The most popular SUDS techniques applied nowadays include filter and infiltration trenches, permeable surfaces, water storage, swales, water harvesting, detention basins, wetlands and ponds $[42,49]$. The devices can be structural by employing mainly fixed physical constructions, such as wetlands, ponds and swales. Non-structural devices involve small scale decentralized facilities such as vegetation and also soft measures using knowledge and practice to influence the behavior and attitude of stakeholders, e.g., training and education programs, policies and laws [20,78-80]. In practice, SUDS is often a mix of both types of measures to make the best use of both their functions. Furthermore, SUDS techniques can be centralized measures targeting point source of pollution and/or decentralized small-scale solutions combating diffuse pollution [23]. All the mentioned SUDS devices can be used individually or combined in series to provide services at different temporal and spatial scales. 
From a hydrological point of view, SUDS measures can be classified into three groups based on their impacts on the water runoff and routing process [49,81]. The first group refers to source control measures aimed at detaining and attenuating excess water runoff upstream, such as local infiltration, impervious pavements and green roofs. On-site control measures focus on preventing and reducing flood hazard impacts on recipient susceptibility, such as individual assets protection and topographic modification. The third group includes downstream measures concerning the conveyance capacity of the system $[16,82]$.

One successful application of permeable pavements to mitigate stormwater runoff was presented in Jayasuriya et al., which shows the potential of pervious pavement to reduce peak flow and to improve water quality in extreme rainfall [41]. Stewart and Hytiris demonstrated a case study using SUDS techniques (mainly swales, filter drains and an infiltration basin) to mitigate the risk of flooding in a new development area [47]. The results showed a promising performance of the SUDS to provide storage capacity for extreme rainfall and water quality control to meet the good status required by the WFD. Another good example of the utilization of SUDS techniques is introduced by Holman-Dodds et al. showing the effects on water runoff by means of manipulating the layout of the urbanized landscape [83]. Nascimento et al. [84] presented a case study using a detention basin in combination with upstream infiltration and a grass swale system for local flood management.

Despite the many benefits of SUDS for water quantity and quality management, there have also been questions and skepticism regarding their performance and feasibility. For example, Bergman et al. [85] examined the performance of two stormwater infiltration trenches installed in late $90 \mathrm{~s}$ in central Copenhagen, Denmark, and revealed that the life-span of the infiltration trenches was much shorter than expected due to sand clogging effects. Similar concerns were shared by Achleitner et al. [86] on the hydraulic permeability of an infiltration and swale system. Their results show that the measured chemical conditions of the soil material are strongly influenced by the initial background concentrations. Zhou et al. described a case study using infiltration trenches and detention ponds to mitigate flood risk under climate change impacts [26]. The paper showed the great potential of detention basins in attenuating water runoff in extreme events and providing additional recreational amenities in the urban landscape. Nevertheless, concerns of the practical operation and maintenance of the ponds were also raised, due to e.g. geological and spatial limitations, problems associated with urban erosion, water pollution and the lack of regulation measures. Furthermore, several studies discussed the limitations of the SUDS techniques in response to the increasing hydrological and hydraulic loading under climate change impacts $[19,83,84]$. It was found that the SUDS techniques impact water flows; however, the reduction of water volume is very limited in extreme events and sensitive to local conditions, such as size and duration of rainfall event, soil material and texture. Therefore, it is wise to appropriately integrate SUDS and traditional drainage solutions to enhance their synergy for drainage design. 


\section{Sustainable Assessment Tools}

\subsection{Models}

Nowadays, there are dozens of commercial and open-source software packages available for modelling of sustainable drainage techniques and devices in terms of both water quantity and quality simulations [42,87]. Although methods of drainage modelling have taken a leap forward due to advances in measurement and computational techniques, they are still an approximation of a practical complex phenomenon. Nevertheless, the modelling approaches contribute to an improved process understanding of the SUDS practices (e.g., flow mechanism, sources of pollutants, cause of flooding) and facilitate the application of SUDS in the field $[88,89]$.

The literature contains details of many modelling approaches employed for SUDS evaluation in different case studies. Elliott and Trowsdale [42] examined 10 modelling methods for SUDS according to their capacity with respect to water quantity and quality simulations, sustainable drainage device modelling and spatial planning, see Figure 1. The paper shows that most of the reviewed models contain functions on hydrological simulation in terms of rainfall generation and runoff routing and only a few are capable of simulating the drainage network hydraulics, such as SWMM and MOUSE (the old version of Mike Urban). Besides PURRS and WBM, all the remaining models include modelling of sediments, nutrients and heavy metals. Regarding the ability to incorporate sustainable devices, most models can be used to investigate reduced imperviousness, ponds and wetlands, infiltration trenches and swales, even though some models do not present the device explicitly. MUSIC and WBM further include bio-retention devices and rain gardens, and only WBM deals with green roofs specifically. Sharma et al. present a case study carried out in Canberra, where three modelling tools (Aquacycle, MUSIC and PURRS) are used to predict the effects of alternative scenarios for integrated water management [53]. The study provides more insights into the performance of the modelling tools with regards to their simulation of rainwater tanks, greywater use, swales and ponds, and on-site detention tanks. Mitchell et al. [90] reviewed six integrated urban water models (UVQ, Hydro Planner, Krakatoa, Mike Urban, UrbanCycle and WaterCress) based on a quick screen of 65 models in the literature. These models are compared from several aspects, e.g., spatial and temporal representation, climatic inputs, water quality, stormwater, groundwater and wastewater treatment. It was found that all six models cover a good range of spatial scales from lot to region. Only two of the models (Mike Urban and UrbanCycle) are able to model at sub-hourly temporal resolution, whereas the rest of models mainly use a daily time step, which is a very strong limitation for urban drainage applications. Among all the reviewed models, Mike Urban has more advanced water quality algorithms in comparison to Krakatoa, UVQ and Hydro Planner. UrbanCycle and WaterCress barely cover water quality simulation in their methods.

Additionally, there are a few reviews with more specific focus on one or more aspects of SUDS simulation. For example, Knapp, Durgunoglu and Ortel [89] reviewed current rainfall-runoff modelling methods for stormwater management based on e.g., model inputs, applications and modelling procedures. Obropta and Kardos [91] assessed three approaches (deterministic, stochastic and hybrid) to stormwater quality modelling and showed that the hybrid approaches are more promising to reduce model prediction error and uncertainty. Zoppou [87] reviewed 12 models (DR3 M-QUAL, HSPF, MIKE-SWMM, QQS, STORM, SWMM, SWMM Level 1, the Wallingford Model, BRASS, HEC-5Q, 
QUAL2E-UNCAS and WQRRS) for stormwater quantity and quality simulation and summarized their strengths and limitations in terms of their functionality, accessibility and modelling approaches for water quantity and quality components, and spatial and temporal scales.

Figure 1. Capacity of various models in terms of water quantity simulation, quality simulation, sustainable drainage device modelling and spatial planning, adapted from Elliott and Trowsdale [42].

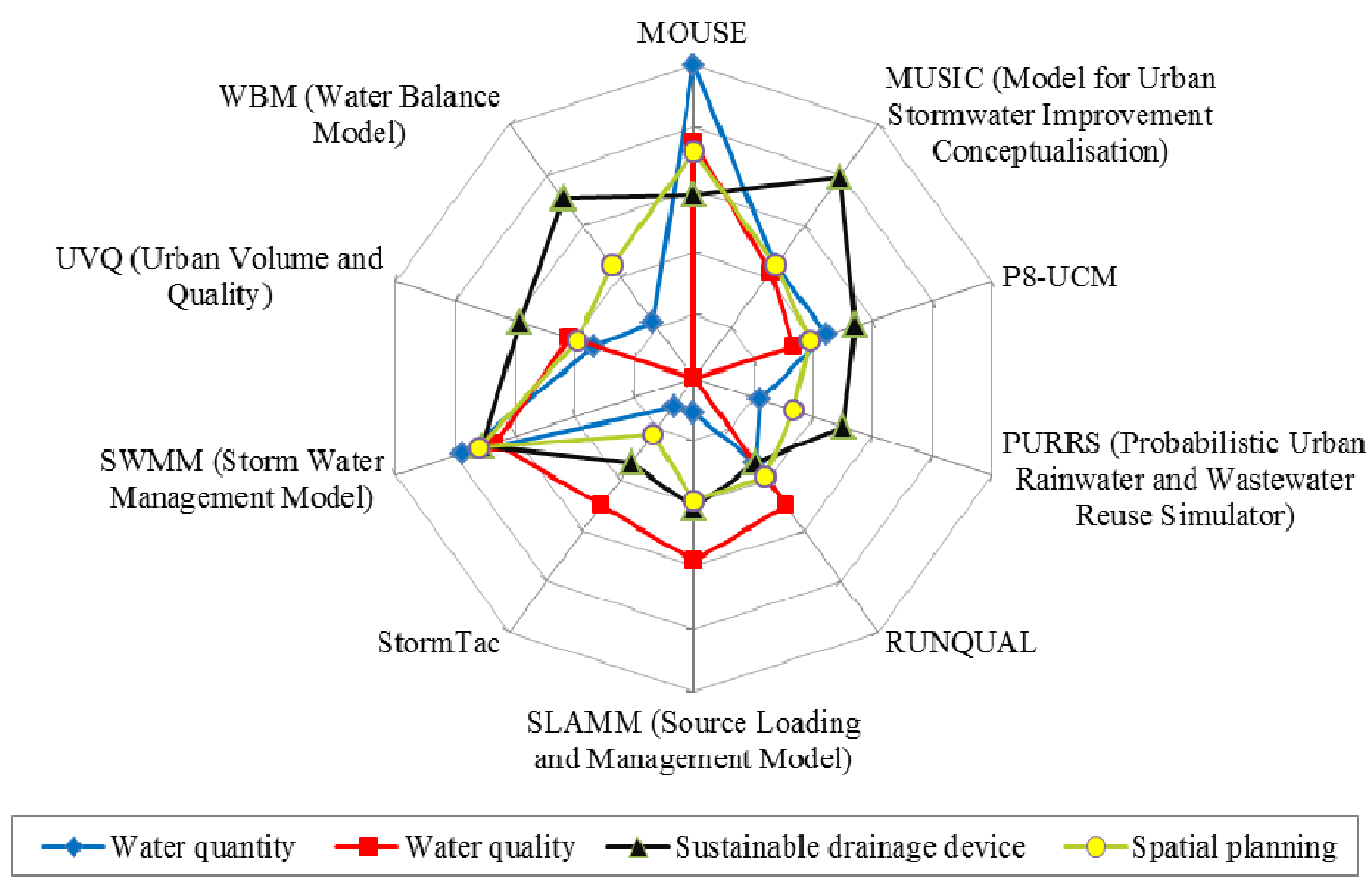

Even with the diverse models for SUDS, many of them are still claimed to be non-user friendly because of their technical complexity [92]. Open-source models require a nominal cost; however, they provide very little technical support for users. In contrast, commercial models support the beginners well, but their costs are often too high for widespread use [87]. Concerns are also expressed due to the lack of a shared interface/platform for the different models. Most models have specialized use for only one or a few aspects of SUDS and therefore the simulation is often performed in isolation and only partially reveals the SUDS's effects. It is difficult for users to know and choose which models to apply and how to extend/integrate them for a more comprehensive SUDS analysis. Even though some models can be poorly integrated, it is tedious and time-consuming to obtain the huge amount of input data for each sub-model [93]. Model integration also faces problems associated with heterogeneous spatial and temporal scales $[90,94]$. This makes it difficult to transfer and use the data among integrated models and thus demands additional work for data preparation and processing. In particular, commercial models run based on executable files and are difficult to modify to interface with other software [87].

The use of geographical information/display (e.g., GIS) in SUDS modeling has also been limited. Most SUDS systems are geographically referenced; integrating SUDS models with GIS system could reduce a huge amount of work on data formatting and process, allowing easy interpretation of model inputs and outputs with a more user-friendly map representation [95]. Certainly, it is also notable that the 
use of GIS will require large spatial and temporal databases, which are challenging to integrate into existing SUDS models.

\subsection{Decision-Aid Tools}

With models of SUDS devices, decision aid tools are further necessary to incorporate the model results and findings in an assessment procedure to facilitate the ranking and selection of drainage alternatives based on the sustainability criteria mentioned previously. Over the years, numerous decision-aid tools emerged in the field to improve the efficiency of decisions; the current review does not attempt to list and discuss all the tools available, just those used commonly for SUDS assessment. A more comprehensive discussion of the various tools can be found in [48,65,96,97].

Figure 2 sorts the reviewed tools into four categories. Economic assessment tools include, but are not limited to Cost-Benefit Analysis (CBA), Cost-Effectiveness Analysis (CEA) and Life-Cycle Costing (LCC). These tools deal with identification and quantification of costs and benefits incorporated in a project/policy [26,48,97]. Social aspects are reflected in tools such as the Social Impact Assessment (SIA), Action research and assessment scales and Triple Bottom Line (TBL) [48,65]. Popular environmental assessment tools for collecting and measuring environmental impacts of projects include Environmental Impact Assessment (EIA), Material Flow Accounting (MFA) and Life-Cycle Assessment (LCA) [96,98]. Health assessment tools are mainly used to evaluate and compare changes in health risks associated with a project. Examples are Risk Assessment (RA), Risk-Risk Analysis (RRA) and Health-Health Analysis (HHA) [97]. Common tools for integrated assessment are Multi-Criteria Analysis (MCA) and Integrated Assessment (IA) [48,65]. These tools use multiple factors to assess the potential of alternative solutions in regard to different criteria. Despite the differences in focus and scope, the tools listed above are not limited to analysis within its category. Depending on the context and the framing of the problem, each tool can be used as an integrated approach for sustainable assessment.

Many recent applications of these decision-aid tools for sustainable drainage assessment can be found in the literature. For instance, Ellis et al. employed a multi-criteria analysis to facilitate the evaluation and assessment of SUDS structures for treatment of highway and urban runoff [69]. Carter and Keeler and Zhou et al. investigated the performance of vegetated roof systems and open urban drainage systems using the cost-benefit approach and revealed the positive socio-economic benefits of the applied SUDS means [26,98]. Linkov et al. reviewed current developments and applications of the comparative risk assessment approach and multi-criteria analysis applied to environmental restoration projects in the United States and Europe [99]. Life cycle cost analysis is applied in Wong et al. to assess the economic benefits of rooftop gardens/green roofs in comparison with regular flat roofs [100]. Lai et al. examined CBA, TBL, IA and MCA tools to address the important role of integrative approaches in sustainable urban water management [65].

Assessment of SUDS solutions, in many cases, requires discussions and reflections of people's preferences, either expressed in monetary terms or in dimensionless weighting/scoring systems [97,101-103]. There are two general ways to capture people's preference in monetary terms: revealed preference techniques which assess preferences by capturing the behavior of customers and stated preference techniques utilizing survey/interview based techniques to uncover underlying preferences [101]. There are plenty of examples using these techniques: studies by Botzen et al. measured people's willingness to pay to avoid negative 
effects caused by flooding using surveys [104]; Lo and Jim investigated the willingness to pay of residents for conservation of urban green spaces in the city of Hong Kong, based on questionnaires using the contingent valuation method [105]. Similar findings were found by Zhou et al., which revealed additional recreational benefits from urban blue-green features by means of the hedonic pricing method [26]. Kenyon [106] employed workshops to reveal participants' thinking and behavior behind decisions using the multi-criteria approach.

Figure 2. Classification of commonly used decision-aid tools in sustainable drainage assessment $[48,65,96,97]$.

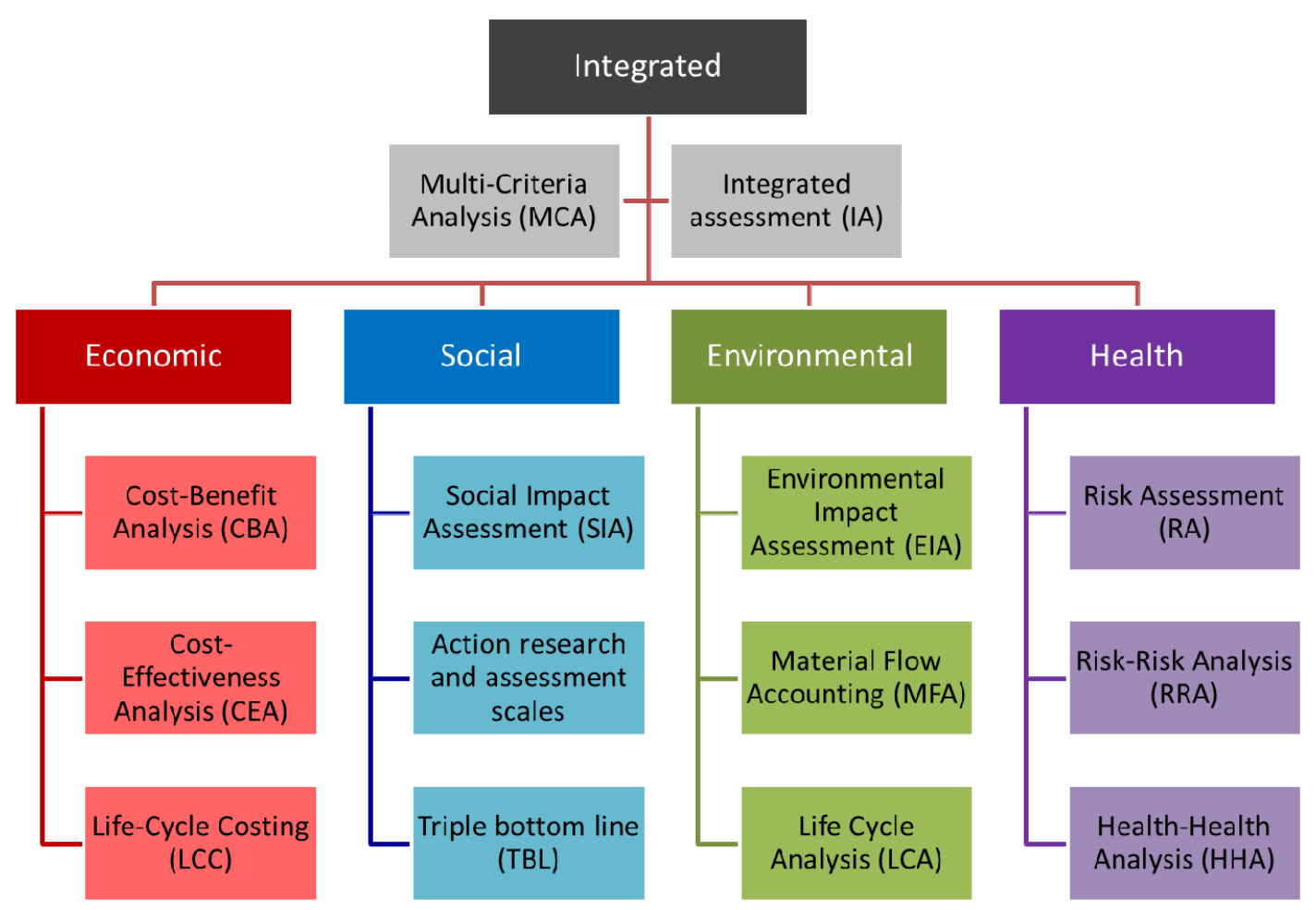

\section{Conclusions}

Sustainable drainage systems are gaining greater importance as a result of increased acknowledgement of the positive effects of such a system on nature and the environment. This paper performs a literature review of recent developments and applications of sustainable drainage systems around the world. It presents the design criteria and techniques of SUDS and various model approaches and decision-aid tools for simulating and assessing sustainable alternatives for drainage design.

Despite the enrichment of the techniques and tools for SUDS, application of sustainable drainage remains a very challenging task in reality. Although available modelling approaches for SUDS have evolved over many years, they are still limited in their mimicking of the natural response of the devices from both a quantity and quality point of view. Many practical implementations of SUDS tend to underestimate their complexity and therefore the resulting performance is often not satisfactory, due to e.g. a lack of experience of SUDS operation and maintenance, ignorance of interaction with other water bodies, and institutional impediments and barriers towards SUDS practices. 
The design of SUDS involves many different disciplines and multidimensional criteria [21]. Nevertheless, most specialists and professionals tend to focus on and prioritize their own fields in the decision making process [64]. As a result, subject-specific techniques/solutions are often applied, which fail to account for important impacts from other fields. An integrated and trans-disciplinary approach will be necessary to incorporate the many disciplines in a common platform to facilitate innovative and sustainable solutions. It is essential for stakeholders to comprehend the broad scope of sustainable design and consider the urban water cycle as a whole planning unit. Meanwhile, climate change and urbanization changes need to be incorporated into the design in order for SUDS to adapt to future changing conditions [72]. In such a context, the future of sustainable drainage design is most likely a mix of both high and low tech solutions to seek a balance between investment cost and performance efficiency. A combination of centralized and decentralized systems will also be necessary to merge the best of the systems and enhance their synergy for sustainable design. To achieve these goals, a design framework integrating technical, social, environmental, economic, legal and institutional aspects will be crucial.

\section{Conflicts of Interest}

The authors declare no conflict of interest.

\section{References}

1. Chocat, B.; Ashley, R.; Marsalek, J.; Matos, M.R.; Rauch, W.; Schilling, W.; Urbonas, B. Toward the sustainable management of urban storm-water. Indoor Built Environ. 2007, 16, 273-285.

2. Larsen, T.A.; Gujer, W. The concept of sustainable urban water management. Water Sci. Technol. 1997, 35, 3-10.

3. Huong, H.T.L.; Pathirana, A. Urbanization and climate change impacts on future urban flooding in Can Tho City, Vietnam. Hydrol. Earth Syst. Sci. 2013, 17, 379-394.

4. Leopold, L.B. Hydrology for Urban Land Planning-A Guidebook on the Hydrologic Effects of Urban Land Use. In Geological Survey Circular 554; U.S. Geological Survey: Washington, DC, USA, 1968.

5. Semadeni-Davies, A.; Hernebring, C.; Svensson, G.; Gustafsson, L.G. The impacts of climate change and urbanisation on drainage in Helsingborg, Sweden: Suburban stormwater. J. Hydrol. 2008, 350, 114-125.

6. Zhou, Q.; Mikkelsen, P.S.; Halsnæs, K.; Arnbjerg-Nielsen, K. Framework for economic pluvial flood risk assessment considering climate change effects and adaptation benefits. J. Hydrol. 2012, 414-415, 539-549.

7. Arora, A.S.; Reddy, A.S. Multivariate analysis for assessing the quality of stormwater from different urban surfaces of the Patiala City, Punjab (India). Urban Water J. 2013, 10, 422-433.

8. Hatt, B.E.; Fletcher, T.D.; Walsh, C.J.; Taylor, S.L. The influence of urban density and drainage infrastructure on the concentrations and loads of pollutants in small streams. Environ. Manag. 2004, 34, 112-124.

9. Wang, J.; Da, L.; Song, K.; Li, B.-L. Temporal variations of surface water quality in urban, suburban and rural areas during rapid urbanization in Shanghai, China. Environ. Pollut. 2008, 152, 387-393. 
10. Echols, S. Artful rainwater design in the urban landscape. J. Green Build. 2007, 2, 103-122.

11. Stahre, P. Sustainability in Urban Storm Drainage: Planning and Examples; Svenskt Vatten: Stockholm, Sweden, 2006.

12. Ferguson, B. The failure of detention and the future of stormwater design. Landsc. Archit. 1991, $81,75-79$.

13. France, R.L. Handbook of Water Sensitive Planning and Design. Integrative Studies in Water Management and Land Development; CRC Press: Boca Raton, FL, USA, 2002.

14. Ellis, J.B.; D’Arcy, B.J.; Chatfield, P.R. Sustainable urban-drainage systems and catchment planning. Water Environ. J. 2002, 16, 286-291.

15. European Commission. Directive 2000/60/EC of the European Parliament and of the Council of 23 October 2000 establishing a framework for Community action in the field of water policy. Off. J. Eur. Communities 2000, 327, 1-72.

16. Krebs, P.; Larsen, T.A. Guiding the development of urban drainage systems by sustainability criteria. Water Sci. Technol. 1997, 35, 89-98.

17. Arisz, H.; Burrell, B.C. Urban Drainage Infrastructure Planning and Design Considering Climate Change; Institute of Electrical and Electronics Engineers (IEEE): New York, NY, USA, 2006; pp. 682-690.

18. United Nations. Agenda 21: Programme of Action for Sustainable Development. United Nations: New York, NY, USA, 1992.

19. Ashley, R.; Garvin, S.; Pasche, E.; Vassilopoulos, A.; Zevenbergen, C. Advances in Urban Flood Management; Ashley, R., Garvin, S., Pasche, E., Vassilopoulos, A., Zevenbergen, C., Eds.; Taylor \& Francis/Balkema: London, UK, 2007.

20. Charlesworth, S.M. A review of the adaptation and mitigation of global climate change using sustainable drainage in cities. J. Water Clim. Chang. 2010, 1, 165-180.

21. Fryd, O.; Dam, T.; Jensen, M.B. A planning framework for sustainable urban drainage systems. Water Policy 2012, 14, 865-886.

22. Faram, M.G.; Ashley, R.M.; Chatfield, P.R.; Andoh, R.Y. Appropriate drainage systems for a changing climate. Proc. ICE Eng. Sustain. 2010, 163, 107-116.

23. Mitchell, G. Mapping hazard from urban non-point pollution: A screening model to support sustainable urban drainage planning. J. Environ. Manag. 2005, 74, 1-9.

24. D'Arcy, B.; Frost, A. The role of best management practices in alleviating water quality problems associated with diffuse pollution. Sci. Total Environ. 2001, 265, 359-367.

25. Roy, A.H.; Wenger, S.J.; Fletcher, T.D.; Walsh, C.J.; Ladson, A.R.; Shuster, W.D.; Thurston, H.W.; Brown, R.R. Impediments and solutions to sustainable, watershed-scale urban stormwater management: Lessons from Australia and the United States. Environ. Manag. 2008, 42, 344-359.

26. Zhou, Q.; Panduro, T.; Thorsen, B.; Arnbjerg-Nielsen, K. Adaption to extreme rainfall with open urban drainage system: An integrated hydrological cost-benefit analysis. Environ. Manag. 2013, 51, 586-601.

27. Fratini, C.F.; Geldof, G.D.; Kluck, J.; Mikkelsen, P.S. Three Points Approach (3PA) for urban flood risk management: A tool to support climate change adaptation through transdisciplinarity and multifunctionality. Urban Water J. 2012, 9, 317-331. 
28. Ranger, N.; Hallegatte, S.; Bhattacharya, S.; Bachu, M.; Priya, S.; Dhore, K.; Rafique, F.; Mathur, P.; Naville, N.; Henriet, F.; et al. An assessment of the potential impact of climate change on flood risk in Mumbai. Clim. Change 2011, 104, 139-167.

29. Willems, P.; Arnbjerg-Nielsen, K.; Olsson, J.; Nguyen, V.T.V. Climate change impact assessment on urban rainfall extremes and urban drainage: Methods and shortcomings. Atmos. Res. 2012, 103, 106-118.

30. Hallegatte, S.; Ranger, N.; Mestre, O.; Dumas, P.; Corfee-Morlot, J.; Herweijer, C.; Wood, R.M. Assessing climate change impacts, sea level rise and storm surge risk in port cities: a case study on Copenhagen. Clim. Change 2011, 104, 113-137.

31. Lenderink, G.; Van Meijgaard, E. Increase in hourly precipitation extremes beyond expectations from temperature changes. Nat. Geosci. 2008, 1, 511-514.

32. Willems, P.; Olsson, J.; Arnbjerg-Nielsen, K.; Beecham, S.; Pathirana, A.; Gregersen, I.B.; Madsen, H.; Nguyen, V.-T.-V. Impacts of Climate Change on Rainfall Extremes and Urban Drainage; IWA Publishing: London, UK, 2012; p. 252.

33. Arnbjerg-Nielsen, K. Quantification of climate change effects on extreme precipitation used for high resolution hydrologic design. Urban Water J. 2012, 9, 57-65.

34. Ekström, M.; Fowler, H.J.; Kilsby, C.G.; Jones, P.D. New estimates of future changes in extreme rainfall across the UK using regional climate model integrations. 2. Future estimates and use in impact studies. J. Hydrol. 2005, 300, 234-251.

35. Mailhot, A.; Duchesne, S. Design criteria of urban drainage infrastructures under climate change. J. Water Resour. Plan. Manag. Asce 2010, 136, 201-208.

36. Burrell, B.C.; Davar, K.; Hughes, R. A review of flood management considering the impacts of climate change. Water Int. 2007, 32, 342-359.

37. Wilderer, P.A. Applying sustainable water management concepts in rural and urban areas: Some thoughts about reasons, means and needs. Water Sci. Technol. 2004, 49, 8-16.

38. Li, G.F.; Xiang, X.Y.; Tong, Y.Y.; Wang, H.M. Impact assessment of urbanization on flood risk in the Yangtze River Delta. Stoch. Environ. Res. Risk Assess. 2013, 27, 1683-1693.

39. Burton, A.; Pitt, R. Stormwater Effects Handbook: A Toolbox for Watershed Managers, Scientists, and Engineers; CRC/Lewis Publishers: Boca Raton, FL, USA, 2001.

40. Hardy, M.J.; Kuczera, G.; Coombes, P.J. Integrated urban water cycle management: The UrbanCycle model. Water Sci. Technol. 2005, 52, 1-9.

41. Jayasuriya, L.N.N.; Kadurupokune, N.; Othman, M.; Jesse, K. Contributing to the sustainable use of stormwater: The role of pervious pavements. Water Sci. Technol. 2007, 56, 69-75.

42. Elliott, A.H.; Trowsdale, S.A. A review of models for low impact urban stormwater drainage. Environ. Model. Softw. 2007, 22, 394-405.

43. Chocat, B.; Ashley, R.; Marsalek, J.; Matos, M.R.; Rauch, W.; Schilling, W.; Urbonas, B. Urban Drainage-out-of-Sight-out-of-Mind? In Proceedings of 5th International Conference on Sustainable Techniques and Strategies in Urban Water Management, Lyon, France, 6-10 June 2004.

44. Keller, E.A.; Hoffman, E.K. Urban streams: Sensual blight or amenity? J. Soil Water Conserv. 1977, 32, 237-240.

45. Zevenbergen, C.; Veerbeek, W.; Gersonius, B.; van Herk, S. Challenges in urban flood management: Travelling across spatial and temporal scales. J. Flood Risk Manag. 2008, 1, 81-88. 
46. Wong, T.; Eadie, M. Water Sensitive Urban Design-A Paradigm Shift in Urban Design. In Proceedings of the 10th World Water Congress, Melbourne, Australia, 12-16 March 2000.

47. Stewart, R.; Hytiris, N. The Role of Sustainable Urban Drainage Systems in Reducing the Flood Risk Associated with Infrastructure. In Proceedings of 11th International Conference on Urban Drainage, Edinburgh, UK, 31 August-5 September 2008.

48. Hellström, D.; Jeppsson, U.; Kärrman, E. A framework for systems analysis of sustainable urban water management. Environ. Impact Assess. Rev. 2000, 20, 311-321.

49. FLOODsite. Flood Risk Assessment and Flood Risk Management. An Introduction and Guidance Based on Experiences and Findings of FLOODsite (An EU-Funded Integrated Project); Deltares/Delft Hydraulics: Delft, the Netherlands, 2009.

50. Sieker, H.; Helm, B.; Krebs, P.; Schlottmann, P.; Tränkner, J. Flexibility-A Planning Criterion for Stormwater Management. In Proceedings of 11th International Conference on Urban Drainage, Edinburgh, UK, 31 August-5 September 2008.

51. Butler, D.; Parkinson, J. Towards sustainable urban drainage. Water Sci. Technol. 1997, 35, 53-63.

52. BMT WBM Pty Ltd. Evaluating Options for Water Sensitive Urban Design-A National Guide; Joint Steering Committee for Water Sensitive Cities: Brisbane, Australia, 2009.

53. Sharma, A.K.; Gray, S.; Diaper, C.; Liston, P.; Howe, C. Assessing integrated water management options for urban developments - Canberra case study. Urban Water J. 2008, 5, 147-159.

54. Coffman, L.S.; Cheng, M.; Weinstein, N.; Clar, M. Low-Impact Development Hydrologic Analysis and Design. In Proceedings of the 25th Annual Conference on Water Resources Planning and Management, Chicago, IL, USA, 7-10 June 1998.

55. County, P.G.S. Low-Impact Development Design Strategies: An Integrated Design Approach; Department of Environmental Resources, Programs and Planning Division: Prince George's County, MD, USA, 1999.

56. Dietz, M. Low impact development practices: A review of current research and recommendations for future directions. Water Air Soil Pollut. 2007, 186, 351-363.

57. VAND I BYER. Available online: http://www.vandibyer.dk/ (accessed on 15 January 2014).

58. Fryd, O.; Backhaus, A.; Jeppesen, J.; Ingvertsen, S.T.; Birch, H.; Bergman, M.; Petersen, T.E.P.; Fratini, C.; Jensen, M.B. Connected Disconnections: Conditions for Landscape-Based Disconnections of Stormwater from the Copenhagen Sewer System in the Catchment Area for River Harrestrup. The 2BG Project Working Report: River Harrestrup Case Study; Danish Centre for Forest, Landscape \& Planning, University of Copenhagen: Copenhagen, Denmark, 2009.

59. Hennelly, B. SuDS-Principles and Drivers; Dublin City Council: Dublin, Ireland, 2005.

60. Malmqvist, P.-A. Sustainable urban water management. Vatten 1999, 55, 7-17.

61. Wong, T.; Brown, R. The water sensitive city: Principles for practice. Water Sci. Technol. 2009, $60,673-682$.

62. Wong, T.H.F. Water sensitive urban design-the journey thus far. Aust. J. Water Resour. 2006, 10, 213-222.

63. Langenbach, H.; Eckart, J.; Schröder, G. Water Sensitive Urban Design-Results and Principles. In Proceedings of the 3rd SWITCH Scientific Meeting, Belo Horizonte, Brazil, 30 November-4 December 2008. 
64. Brown, R.R.; Farrelly, M.A. Delivering sustainable urban water management: A review of the hurdles we face. Water Sci. Technol. 2009, 59, 839-846.

65. Lai, E.; Lundie, S.; Ashbolt, N.J. Review of multi-criteria decision aid for integrated sustainability assessment of urban water systems. Urban Water J. 2008, 5, 315-327.

66. Woods-Ballard, B.; Kellagher, R.; Martin, P.; Jefferies, C.; Bray, R.; Shaffer, P.; Kellagher, R. The SUDS Manual (C697); Construction Industry Research \& Information Association (CIRIA): London, UK, 2007.

67. Malmqvist, P.-A.; Heinicke, G.; Kärrman, E.; Stenström, T.A.; Svensson, G. Strategic Planning of Sustainable Urban Water Management; IWA Publishing: London, UK, 2006.

68. Connor, R.; Dovers, S. Institutional Change for Sustainable Development; Edward Elgar: Cheltenham, UK, 2004.

69. Ellis, J.B.; Deutsch, J.C.; Mouchel, J.M.; Scholes, L.; Revitt, M.D. Multicriteria decision approaches to support sustainable drainage options for the treatment of highway and urban runoff. Sci. Total Environ. 2004, 334-335, 251-260.

70. Berke, P.R. Does sustainable development offer a new direction for planning? Challenges for the Twenty-First Century. J. Plan. Lit. 2002, 17, 21-36.

71. Makropoulos, C.K.; Natsis, K.; Liu, S.; Mittas, K.; Butler, D. Decision support for sustainable option selection in integrated urban water management. Environ. Model. Softw. 2008, 23, 1448-1460.

72. Miguez, M.G.; Veról, A.P.; Carneiro, P.R.F. Sustainable Drainage Systems: An Integrated Approach, Combining Hydraulic Engineering Design, Urban Land Control and River Revitalisation Aspects. In Drainage Systems; Javaid, M.S., Ed.; InTech: Rijeka, Croatia, 2012.

73. Pahl-Wostl, C. Towards sustainability in the water sector-The importance of human actors and processes of social learning. Aquat. Sci. 2002, 64, 394-411.

74. Pearson, L.J.; Coggan, A.; Proctor, W.; Smith, T.F. A sustainable decision support framework for urban water management. Water Resour. Manag. 2010, 24, 363-376.

75. Rauch, W.; Seggelke, K.; Brown, R.; Krebs, P. Integrated approaches in urban storm drainage: Where do we stand? Environ. Manag. 2005, 35, 396-409.

76. Novotny, V. Sustainable Urban Water Management. In Water and Urban Development Paradigms: Towards An Integration of Engineering, Design and Management Approaches; Taylor and Francis Group: London, UK, 2009; pp. 19-31.

77. Geldof, G.D.; Kluck, J. The Three Points Approach. In Proceedings of 11 th International Conference on Urban Drainage, Edinburgh, UK, 31 August-5 September 2008.

78. Dawson, R.J.; Ball, T.; Werritty, J.; Werritty, A.; Hall, J.W.; Roche, N. Assessing the effectiveness of non-structural flood management measures in the Thames Estuary under conditions of socio-economic and environmental change. Glob. Environ. Change 2011, 21, 628-646.

79. Kundzewicz, Z.W. Non-structural flood protection and sustainability. Water Int. 2002, 27, 3-13.

80. Taylor, A.; Wong, T.H.F. Non-structural Stormwater Quality Best Management Practices-A Survey Investigating their Use and Value. In Cooperative Research Centre for Catchment Hydrology; Technical Report 02/12; Monash University: Melbourne, Australia, 2002. 
81. Graham, A.; Day, J.; Bray, B.; Mackenzie, S. Sustainable drainage systems-A guide for local authorities and developers. Available online: http://www.rspb.org.uk/Images/SuDS_report_final_ tcm9-338064.pdf (accessed on 23 September 2013).

82. Zhou, Q. Urban Drainage Design and Climate Change Adaptation Decision Making. Ph.D. Thesis. Department of Environmental Engineering, Technical University of Denmark, Lyngby, Denmark, October 2012.

83. Holman-Dodds, J.K.; Bradley, A.A.; Potter, K.W. Evaluation of hydrologic benefits of infiltration based urban storm water management. J. Am. Water Resour. Assoc. 2003, 39, 205-215.

84. Nascimento, N.O.; Ellis, J.B.; Baptista, M.B.; Deutsch, J.C. Using detention basins: Operational experience and lessons. Urban Water 1999, 1, 113-124.

85. Bergman, M.; Hedegaard, M.R.; Petersen, M.F.; Binning, P.; Mark, O.; Mikkelsen, P.S. Evaluation of two stormwater infiltration trenches in central Copenhagen after 15 years of operation. Water Sci. Technol. 2011, 63, 2279-2286.

86. Achleitner, S.; Engelhard, C.; Stegner, U.; Rauch, W. Local infiltration devices at parking sites-Experimental assessment of temporal changes in hydraulic and contaminant removal capacity. Water Sci. Technol. 2007, 55, 193-200.

87. Zoppou, C. Review of urban storm water models. Environ. Model. Softw. 2001, 16, 195-231.

88. Hamby, D.M. A review of techniques for parameter sensitivity analysis of environmental models. Environ. Monit Assess. 1994, 32, 135-154.

89. Knapp, H.V.; Durgunoglu, A.; Ortel, T.W. A Review of Rainfall-runoff Modeling for Stormwater Management; SWS Contract Report 516; Illinois State Water Survey, Hydrology Division: Champaign, IL, USA, 1991.

90. Mitchell, V.G.; Duncan, H.; Inma, R.M.; Stewart, J.; Vieritz, A.; Holt, P.; Grant, A.; Fletcher, T.D.; Coleman, J.; Maheepala, S.; et al. State of the Art Review of Integrated Urban Water Models; Novatech: Lyon, France, 2007; pp.1-8.

91. Obropta, C.C.; Kardos, J.S. Review of urban stormwater quality models: Deterministic, stochastic, and hybrid approaches. JAWRA J. Am. Water Resour. Assoc. 2007, 43, 1508-1523.

92. Viavattene, C.; Scholes, L.; Revitt, D.M.; Ellis, J.B. A GIS based decision support system for the implementation of Stormwater Best Management Practices. In Proceedings of 11th International Conference on Urban Drainage, Edinburgh, UK, 31 August-5 September 2008.

93. Hossaina, I.; Imteaz, M.A. CatStream: An Integrated Catchment-Stream Water Quality Model. In Proceedings of 20th International Congress on Modelling and Simulation, Adelaide, Australia, 1-6 December 2013.

94. Schmitt, T.G.; Huber, W.C. The Scope of Integrated Modeling-System Boundaries, Sub-Systems, Scales and Disciplines. In Proceedings of 10th International Conference on Urban Drainage, Copenhagen, Denmark, 21-26 August 2005.

95. Sample, D.; Heaney, J.; Wright, L.; Koustas, R. Geographic information systems, decision support systems, and urban storm-water management. J. Water Resour. Plan. Manag. 2001, 127, 155-161.

96. Ashley, R.; Blackwood, D.; Butler, D. Sustainable Water Services: A Procedural Guide; IWA Publishing: London, UK, 2004. 
97. Pearce, D.; Atkinson, G.; Mourato, S. Cost-Benefit Analysis and the Environment: Recent Developments; Organisation for Economic Co-operation and Development (OECD): Paris, France, 2006.

98. Carter, T.; Keeler, A. Life-cycle cost-benefit analysis of extensive vegetated roof systems. $J$. Environ. Manag. 2008, 87, 350-363.

99. Linkov, I.; Satterstrom, F.K.; Kiker, G.; Batchelor, C.; Bridges, T.; Ferguson, E. From comparative risk assessment to multi-criteria decision analysis and adaptive management: Recent developments and applications. Environ. Int. 2006, 32, 1072-1093.

100. Wong, N.H.; Tay, S.F.; Wong, R.; Ong, C.L.; Sia, A. Life cycle cost analysis of rooftop gardens in Singapore. Build. Environ. 2003, 38, 499-509.

101. Bateman, I.J.; Carson, R.T.; Day, B.; Hanemann, M.; Hanley, N.; Hett, T.; Jones-Lee, M.; Loomes, G.; Mourato, S.; Özdemiroglu, E.; et al. Economic Valuation with Stated Preference Techniques: A Manual; Edward Elgar Publishing Ltd: London, UK, 2002.

102. Ready, R.C.; Berger, M.C.; Blomquist, G.C. Measuring amenity benefits from farmland: Hedonic pricing vs. contingent valuation. Growth Change 1997, 28, 438-458.

103. Taylor, L.O. The Hedonic Method. In A Primer on Nonmarket Valuation; Champ, P.A., Boyle, K.J., Brown, T.C., Eds.; Kluwer Academic Publishers: Boston, London, 2003; Chapter 10. pp. 331-393.

104. Botzen, W.J.W.; Aerts, J.; van den Bergh, J. Willingness of homeowners to mitigate climate risk through insurance. Ecol. Econ. 2009, 68, 2265-2277.

105. Lo, A.Y.; Jim, C.Y. Willingness of residents to pay and motives for conservation of urban green spaces in the compact city of Hong Kong. Urban For. Urban Green. 2010, 9, 113-120.

106. Kenyon, W. Evaluating flood risk management options in Scotland: A participant-led multi-criteria approach. Ecol. Econ. 2007, 64, 70-81.

(C) 2014 by the authors; licensee MDPI, Basel, Switzerland. This article is an open access article distributed under the terms and conditions of the Creative Commons Attribution license (http://creativecommons.org/licenses/by/3.0/). 